\title{
Does Financing Diversification Matter? \\ An Evaluation of the Performance of Savings and Credit Cooperative Societies; a case of Kakamega County, Kenya
}

\author{
${ }^{1}$ Mulwa Jonathan Mwau \\ ${ }^{1}$ Lecturer, Department of Commerce, Murang'a University College, Kenya and a Ph.D (Finance) student, Moi \\ University, Kenya \\ Email:jmwau@yahoo.com
}

\begin{abstract}
Financial sector liberalization in Kenya and the far world has created an enormous spectrum from which Savings and Credit Cooperative Societies (Saccos) can raise finances from. This has coincided with a period of good performances for a number of Saccos. However, there is no certain indication of a link between the good performance and the financing diversification; it is not clear whether those Saccos who have diverse financing sources perform any better than those who rely on their members' savings. This paper therefore sought to establish the effect of financing diversification on the performance of Saccos by answering the question; does financing diversification affect the performance of a Sacco? The study used a descriptive correlational design with the study population being all Kenya Union of Savings and Credit Cooperatives (KUSCCO) member Saccos registered in Kakamega County. Data was collected from a key informant in every Sacco using a questionnaire and analysed using both descriptive and inferential statistics. Descriptive analysis was done to identify any trends and dispersions in the data while Karl Pearson's zero order coefficient of correlation was used to determine the nature of relationship between financing diversification and Sacco performance. Regression analysis was done to model the relationship between financing diversification and Sacco performance. The study found out that financing diversification had a significant positive effect on Sacco performance. The study has, however, recommended further researches to establish the risk implications of financing diversification on Saccos.
\end{abstract}

\section{Keywords}

Financing diversification, Performance, Saccos

\section{Academic Discipline}

Business: Finance

\section{SUBJECT CLASSIFICATION}

Business Subject Classification

\section{TYPE (METHOD/APPROACH)}

Descriptive correlational design; Questionnaires

\section{Council for Innovative Research}

Peer Review Research Publishing System

Journal: International Journal of Management \& Information Technology

Vol.4, No.3

editor@cirworld.com

www.cirworld.com, member.cirworld.com 
INTRODUCTION

The performance of Kenyan Savings and Credit Cooperative Societies (Saccos) has been improving year in year out. The amount of loans outstanding as well as their membership has been on a rise for the last decade [28] and Saccos have continued to offer new services and credit products to their members while maintaining low interest rates on loans. Indeed most Saccos have been lending at 12 percent per annum, which is lower than what banks have offered even when market rates have been at the lowest [15]. This is in line with keeping with the very traditional, and probably the most important, function of Saccos; the promotion of thrift and exclusive provision of credit facilities to their members, at fair and reasonable cost [32][36].

To finance their loan portfolios, Saccos have traditionally accumulated savings of their members [19] until recently when the financial sector liberalization of 1990s allowed them to diversify their financing sources by offering Front office (FOSA) services [28]. Indeed, over 72 percent of credit unions funds came from customers (members) savings, share draft accounts and share certificates [24] and unlike commercial banks, credit unions seldom purchased funds in the capital or money markets. However, following the recent deregulation of the industry which liberalizes financial institutions operations, credit unions have now become an aggressive competitor of commercial banks and savings associations for not only consumer installment loans but also savings deposits [29]. For instance, the Depository Institutions Deregulation and Monetary Control Act (DIDMCA) of 1980 gave the US credit unions the power to offer checkable deposits (share drafts) and home mortgage (real estate) loans in order to be able to compete effectively with commercial banks [26].

Although credit cooperatives typically derive much of their funding from capital contributions, they can now take deposits [12]. Most pure credit unions are very active in mobilizing savings and the lion's share of their funds comes from members' deposits and share capital. Research has confirmed that most SACCOS around the globe use an array of demand and fixed-term products to mobilize savings [19]. The Demand Deposits do not have predetermined withdrawal dates and allow unlimited withdrawals while the Fixed Term Savings, also called certificates of deposit or programmed savings, are made in one deposit with interest paid upon maturity. There are three main types of accounts through which credit unions raise their funds namely; regular share accounts, share certificate accounts and share draft accounts [24].

Regular share accounts (members' savings) constitute the largest part of a credit union's funding [32]. In 2004 for instance, 86.1 percent of American credit unions funding came from the members' savings [9]. One way in which members remit their savings to a Sacco is through the regular share accounts. A regular share accounts is the savings accounts of members [24]. They are types of payroll savings plans by which employees can automatically set aside a portion of their salary in a savings account [29]. Customers cannot write cheques against these accounts although they can withdraw funds without giving prior notice or incurring any penalties [19]. However, in Kenya as many other countries, shares are not withdrawable and are used as security for loans to members [27]. Additionally, customers do not receive any interest on these accounts [31] but instead receive dividends that are not guaranteed in advance but are estimated [29]. The share account is analogous to a passbook savings account and its return is referred to as a dividend, although it is treated as interest for individual income tax liability purposes.

Another account is the share certificate account which was started in 1978, when credit unions were authorized to offer money market certificates which carried the same terms as the money market deposit plans sold by banks [29]. Share certificates are comparable to the certificates of deposit (CDs) offered by commercial banks [24]. The customers agree to leave their funds on deposit with the credit union for a specified length of time and in exchange receive a higher return. They have been referred to as fixed term savings or programmed savings and are made in one deposit with interest being paid on maturity [19].

A third type of account is the Share drafts which were first developed in 1974 in the United States and their use was legalized in 1980 [24] following the enactment of the Depository Institutions Deregulation and Monetary Control Act (DIDMCA) [26]. This Act gave the US credit unions the power to offer checkable deposits (share drafts) and home mortgage (real estate) loans in order to be able to compete effectively with commercial banks [26]. Share draft accounts are virtually identical to the savings accounts of commercial banks and they not only pay interest but also permit depositors to write share drafts against them in discharge of payments.

In Kenya, following the liberalization of the financial sector in the 1990s [27], the back office model of Sacco operations was found to be inadequate and as a result, many Sacco societies introduced the front office services activities (FOSA) alternatively known as the Sacco Savings Account (SASA). This was motivated by a number of factors including the need to solve the problem of non-remittance through the check-off savings system and was aimed at among other things, improving the Sacco societies' liquidity and the promotion of the owner-user principle. By around 2003, Sacco societies in Kenya were already taking deposits from persons not drawn from the common bond, that is, public deposits [13].

Another way through which credit unions are able to raise their funds is their capital reserves [22]. Capital reserves are "the total of the Sacco's regulatory reserves, undivided or retained earnings, special reserves, and net income that has yet to be closed to the retained earnings account" [37]. Most pure credit unions derive a lion's share of their funds from their members' deposits and capital [12]. As Sacco societies grow and become regulated, the need to build capital reserves becomes a requirement not only from the regulatory authorities but as the most cost-effective financing option for new products, services, marketing and branch network expansion [37]. The NCUA's CAMEL (Capital adequacy, Asset quality, Management, Earnings and Asset/Liability management) rating system [25] provides that capital reserves serve to support 
growth as a free source of funds. Capital reserves represent not only a cushion for uncertainties such as asset losses and adverse economic cycles, but it also provides resources for long-term investments and funding for provision of more services to members [37]. Credit unions capital cannot be measured however, in the usual way since a credit unions share accounts are in fact equity accounts [24]. A meaningful approach is to measure capital as the difference between total assets and total liabilities, where liabilities include all share accounts. Credit unions generate capital for operating funds not by selling stock but by receiving deposits from members and repayment of loans made to members [4].

To raise more funds, the modern day credit unions have expanded their investments in services [29]; some sell life insurance, others act as brokers for group insurance plans where state permits. Many credit unions are now active in offering 24 - hour automated services, financial planning services, retirement savings, home equity and first mortgage loans and payment services, all with a view to increasing their income reserves. However, credit unions' permissible investments in securities are limited to a list prescribed by state regulations [29]. For instance, the Sacco Societies Act of Kenya [34] specifies the various investments that Saccos in Kenya can make. Sec 38 (1) of the Act states that "the funds of a Sacco society may be invested in securities, obligations or other debt instruments issued or guaranteed by the government or any agency of the government; deposits, obligations or other account s of deposit - taking institutions under the Banking Act (Cap 488); shares, stocks, deposits in, loans to or other obligations of any Sacco society or cooperative society. Sec 38(3) of the Act prohibits a Sacco society from purchasing or acquiring any land or any interest or right therein except when it's reasonably necessary for the purpose of conducting the Sacco's deposit-taking business. However, credit unions rely heavily on government securities and savings deposits to provide liquidity to meet deposit withdrawals and accommodate members credit needs [29]. The uses of funds for Saccos are the SACCOs' investments which include loans - which take a major share - , financial investments, liquid investments, non financial investments and other investments in regulated financial institutions [16].

\subsection{Overview of Saccos in Kenya}

In Kenya, the Co-operative Movement can be traced to the very beginning of 1900 [5] though savings and credit cooperative organizations (Saccos) emerged later. The first Kenya's Co-operative Society, Lumbwa Co-operative Society, was formalized in 1908 by European Farmers with the main objective of purchasing farm inputs and of marketing. In 1930, the Kenya Farmers Association was registered as a Co-operative Society to take over the role of the Lumbwa Cooperative Society. African smallholder farmers fought for the formation of their own Cooperatives, but it was not until in the late 1950's that they were allowed to promote and register Cooperatives for cash crops like coffee and pyrethrum and at independence in 1963, there were 1,030 Co-operative Societies in the country (655 active) with a total membership of 355,000 [5].

Despite the early development of cooperative movement in Kenya, the emergence of Saccos dates back to the years 1965-1970 [6]. They grew out of the credit systems of the old farming cooperatives which were common in cash crop areas. At that time, farmers were organized into cooperatives, and financial services were provided by the "union banking sections" where the farmers could save and obtain advances that were repaid using the income earned from the harvest. These banking sections were progressively converted in to Saccos in order to formalize the separation between economic and financial services.

Cooperatives in Kenya have made a remarkable progress in agriculture, banking, credit, agro-processing, storage, marketing, dairy, fishing and housing [17]. To-date, the Co-operative Movement in Kenya commands a substantial portion of this Nation's wealth with over 11,200 registered cooperative societies country-wide and a total of approximately 600,000 active members. The movement has mobilized domestic savings estimated at over Kshs. 125 billion with a membership of over 6.1million [5].

\section{EVIDENCE ON EFFECTS OF DIVERSIFICATION ON PERFORMANCE}

A lot of studies have been carried out on diversification, both in strategic and financial perspectives, and most of these studies point out to a link between diversification and the performance in both financial and non financial institutions. Centre for Higher Education policy Studies [7] investigated the potential link between the funding arrangement and the performance of higher education systems in Europe where it sought to answer the questions; "Do funding arrangements matter?; what has been the impact of the funding reforms on the performance of higher education system?". In this study, financing diversification was characterized by cost sharing and student support loan schemes while higher education performance was characterized by access, mature learners enrolment, graduation, employability, business contributions, international students mobility, research output, capacity to attract funding and cost effectiveness. The study found out that funding reforms led to increased system performance on three performance dimensions (graduation, student contributions and research output) and a weak link existed in three other performance dimensions (Mature learners enrolment, business contributions and international students mobility) with no link between funding reforms and two other dimensions (access and employability). 
In their study of the internal determinants for diversification in banks in India, Arrora and Kaur [1] found out that, four explanatory variables of diversification; risk reduction, cost of production, regulatory control and technological are instrumental in bringing out variations in the income structure of banks. However, this study did not point out specifically to performance but rather on the reasoning for diversification.

A similar study by Landi and Venturelli analyzed the determinants and effects of diversification on efficiency and profitability amongst the European banks and found out that diversification positively affected efficiency in terms of profits, costs and revenue growth [20]. In an earlier study by De Young and Roland on the effects of product mix (diversification) on earnings volatility of commercial banks, it was found out that bank's earnings grow more volatile as banks tilt their product mixes towards fee based activities and away from traditional intermediation services [8].

Fiscal policy and research institute of Korea in its report on regulation and supervision for sound liquidity risk management for banks reports that diversity of financing sources enhances a bank's ability to raise funds in times of financial difficulties and that the main object of diversification is to find alternatives as banks face stress conditions or financial difficulties [10]. Diversification of financing sources forces the banks management to ponder over possible solutions for rainy days. The institute concludes that diversification of financing sources is necessary for sound liquidity management. Though the institute says nothing about the effects of financing diversification on performance of banks, it is imperative that sound liquidity management is key to the good performance of any depository financial institution [3]. Usually, there is a strong link between financing diversification and liquidity management. Additionally financing diversification lessens the dependence of a financial institution on a small set of fund providers [3].

In his work on "capitalization of Oman banks to remain strong", Kawach noted that greater financing diversification is good for a banking institution because increasing the duration of liabilities helps reduce maturity mismatches [14]. TumpelGugerell in her paper; "Business models in banking; is there a best practice?" notes that there has been a shift in banks business models from the traditional model of financing, which entailed a heavy reliance on retail deposits, to an increasing reliance on market based sources of funding [35]. However, she quantifies the effects of this shift on only a single performance measure; expansion of bank loans. This is erroneous since loans are not the only measure of a financial institution's performance; there are other measures which she did not consider.

All these studies point to a positive link between diversification and performance. In Cheps, funding reforms improved the performance of the European education system on a number of performance measures [7] while Arrora and Kaur concluded that diversification brings about variations in the income structures of Indian banks [1]. In Landi and Venturelli, diversification positively affected the efficiency of European banks in terms of profitability, costs and revenue growth [20] while in De Young and Roland product diversification towards fee based activities and away from the traditional intermediation services increased the earnings volatility of banks [8]. The Fiscal policy and research institute of Korea [10] and the BIS [3] asserted that financing diversification improves the liquidity position of financial institutions while in her paper; Tumpel-Gugerell concludes that, use of market based sources of funding leads to expansion of bank loans [35].

Expectedly, most financial institutions in Kenya have embarked on diversifying their financing sources in search of improved performance, Saccos included. Though is supported by research, not one of these earlier studies on diversification touched on the impact of diversification on the performance of Sacco societies, whether from a strategic or financial perspective. There is therefore a wide rift of knowledge in the area of diversification in Sacco societies which prompted this study.

\section{OBJECTIVE AND PERFORMANCE OF SACCOS}

Credit unions are non-profit institutions [24] [29] [31] and therefore, their performance cannot be measured and evaluated in terms of profitability [26]. "Given the mutual-ownership status of credit unions, return on assets (or profits) is not necessarily the primary goal of credit unions, but this not-for-profit industry has a primary goal of serving the deposit and lending needs of its members" [32]. Though they charge interest on their loans, this is not meant to earn them a profit but rather to cover interest cost on savings and the cost of administration [31. This contrasts with the emphasis placed on profitability by stockholder-owned commercial banks and savings institutions.

Understanding the primary objective in the formation of any entity is paramount to evaluating its performance. Various authors and institutions have highlighted the primary objective of a Sacco. The key objective of a Sacco society is to promote thrift among its members by affording them an opportunity for accumulating their savings and to create thereby a source of funds from which loans can be made to them exclusively for provident and productive purposes, at fair and reasonable rates of interest; thereby enabling the members to use and control their money for their mutual benefits [36]. Saunders and Cornett concurs that "the primary objective of credit unions is to satisfy the depository and borrowing needs 
of their members" [32]. This was emphasized in one of the traditional definitions of credit unions that a credit union is a cooperative association organized for the purpose of promoting thrift among its members and creating a source of credit for provident and productive purposes.

The most basic function of a Sacco Society is financial intermediation; that is bringing savers and borrowers together in a system that enables them to pool their money as savings and shares, and after capturing funds, transforming them into loans by calculating all of the costs of doing this business to make it useful to both the Sacco Society and its members [33]. Indeed the fundamental motivation of a credit union is to provide financial services to the membership, in particular a depository for savings and access to consumer and mortgage credit.

The arguments by various authors on the functions and objectives of credit unions provide the yard stick upon which the performance of a Sacco society can be measured. The starting point in evaluating a Sacco's performance is its ability to mobilize members' savings. Various authors agree that Sacco societies should help their members to accumulate their savings. This is however a bridge towards the second and most important objective of a Sacco society; that of offering loans or credit facilities. This has been confirmed by Kwame who contents that in Africa, credit unions are known as Savings and Credit Co-operative Societies (Saccos) to emphasize savings before credit [19]. A meeting point in the various definitions of credit unions is that the core function of a Sacco society is to mobilize savings with the intention of affording members credit facilities. Therefore, one of the key measures of a Sacco's performance is the amount of loans that a Sacco society is able to advance to its members.

Equally important is the cost that the Sacco society charges its members for the loans advanced to them. Interest rates charged by Sacco societies are decided by their members and should be fair to the members. Credit unions should make loans to its members at reasonable rates of interest [31]. Credit unions are able to charge lower interest rates to their partly because they are non-profit oriented and partly because they enjoy a cost advantage of being tax exempt [24]. Additionally, credit unions enjoy a lot of gratuitous (volunteer) benefits from its members in an attempt to reduce their operation costs [24] since any cost reductions are passed on to the depositors (members) and therefore the volunteers feel they are working for the common good. Frequently, the sponsoring employer or association provides free office facilities and credit union members elect directors and officers who frequently serve with no compensation at all [29]. Another factor that enables credit unions charge a lower rate of interest is that they experience lower levels of default. The members of a credit union have a common bond which makes them committed to meeting their obligations with the credit union [21]. Therefore, credit cooperatives have the potential to provide affordable credit to their members because they can reduce transaction costs and have a lower risk of default [12]. Even in some instances, credit unions frequently grant their members interest refunds up to 20 percent of the amount of interest due from a loan [29] in addition to accepting a very small spread between their loan and deposit interest rates.

Another important indicator of a Sacco's performance is the time it takes between when a loan facility is requested and when the Sacco actually grants the facility. If a Sacco cannot provide a loan as and when a member needs it, then it will be failing in its duty of service to members [37].To be successful and sustainable a Sacco Society should function similar to banks as a market for money in a group sharing a common bond, mobilizing money from members as savings, shares and providing easy accessible loans to members on time [33]. From these views, it can be concluded that the function of a Sacco society is not just to provide loans but those loans should be easily accessible and available to members on time. The loan turnaround time is not only necessary but of essence for any successful and Sustainable Sacco society.

Yet another important indicator of a credit unions performance is the number of its members who benefit from credit facilities. Over $61.4 \%$ of a credit unions assets are invested in loans advanced to its members [29]. These loans are usually relatively small in keeping with the mission of credit unions to provide loans to small borrowers [12] and therefore the number of loan beneficiaries is a more important indicator of a Sacco society's performance than may be the total volume or amount of the loans.

Another dimension on which the performance of a Sacco can be evaluated is on the ratio of loans given to a member relative to the member's savings with the Sacco. Usually, Sacco loan size is based on leveraging or a "multiple" of a member's share and deposit account balances, which guaranteed the loan [2]. The leveraged funds are usually not withdrawable from the credit union while the loan is still outstanding. This ratio is usually not fixed but depends on the Sacco's policy but normally Saccos usually give loans to their members equal to three times a member's savings [27] This multiple ranges between three and five times the sum of both shares and savings deposits [2].

\section{METHODOLOGY}

This study used a descriptive correlational design as it sought to describe and explain the relationship between the study variables. Primary data was collected from a key informant in all the sixteen KUSCCO-member Saccos whose registered offices are in the study area and were still in existence at the time of the study in 2011. Questionnaires were the primary 
data collection instruments and included both open and closed ended questions. The research variables were measured using Ordinal and Likert-type scales because they not only have more informational value compared to other similar scales (e.g. Thurstone-type scale) but also come handy in respondent centred studies [18]. The questionnaire was piloted for validity and Cronbach's alpha coefficient used to test the reliability of the measurement scales giving a cronbach's alpha coefficient of 0.7743 for dependent variable measures and 0.7039 for independent variable measures which is above the minimum acceptable threshold of 0.70 [30]. The questionnaire was administered personally by the researcher and the data analyzed both descriptively and inferentially. $93.75 \%$ of the questionnaires that were administered were returned which represents a reliable response rate [11].

\section{$5 \quad$ RESULTS AND DISCUSSIONS}

The following section presents both the descriptive and inferential results of the study:

\subsection{Channels of diversification}

The various ways through which a Sacco can raise finances for operations anticipated in this study were members' contributions (savings), operating deposit accounts and income funds from investments, accumulation of funds, otherwise called capital reserves and fee income from services. All the Saccos at least raised funds from their members' savings. This was in line with the proposition by the American Federal Reserve [9], Mishkin and Eakins [24], Saunders and Cornett [32], and Kwame [19] that Saccos derive much of their funding from members' contributions which Huppi and Feder [12] called the lion's share of their funds.

To establish whether a Sacco raised funds from the other channels of financing, respondents were required to state whether they were using any of the various other channels of financing and it was found that 42.9 percent of the Saccos operated deposit facilities while 85.7 percent had investments. Some of the account facilities operated by Saccos were junior savings accounts, salary accounts, normal savings accounts and special savings accounts like; Christmas packages and school fees packages. Among the investment facilities were shares with KUSCCO and shares with public quoted companies among them the Cooperative bank of Kenya.

Another way through which Saccos financed their operations was through accumulating funds. To evaluate the extent of funds retention, respondents were required to react to the statement that their Sacco used all funds immediately they were received. This was intended to determine whether the Sacco retained any funds. 72.7 percent of the respondents disagreed to this statement, implying that their Saccos did not use all the funds when they are received and therefore they retained part of their funds. Only 27.3 percent agreed to this statement with the implication that they did not retain any funds. To ascertain whether this retention was deliberate, the respondents were required to react to a statement that their Saccos had retention policy on a scale. 83.3 percent agreed to have a policy to retain funds with only 16.7 percent disagreeing. This implies that the retention of funds was majorly deliberate and not a matter of chance.

\subsection{Sacco performance}

Sacco performance was the dependent variable in this study and was characterized by volume of loans, number of loanees, interest rate on loans, loan application turn-around time and the ratio of loan to member's savings. The analysis in this section sought to identify any trends in the various dimensions of this variable.

To assess the different types of loans offered by the Saccos, the respondents were requested to state the various types of loans offered by the Saccos. The responses showed that the Saccos offered normal loans, school fees loans, emergency loans, refinance (top-up) loans, new members introduction (baggage and passage) loans, express (instant) loans, special advance loans, asset purchase loans, Salary advance, tender advance, FOSA loans, crop advance and BOSA loan advance.

To investigate whether the number and volume of loans given by a Sacco were in any way linked to the amount of funds at the disposal of the Sacco, the respondents were required to react to a statement that their Sacco gives more loans when it had more funds. The results showed that 92.9 percent agreed that their Saccos gave more loans when they had more funds with only 7.1 percent disagreeing. This implies that most of the Saccos would increase the volume and number of loans when they had the funds.

The Saccos took varied time periods to process a loan application depending on the type of loan. However, to determine whether the amount of time taken between when a loan facility is requested for by a member and when it's actually granted is in any sense related to availability of funds, respondents were requested to react to a statement that their Sacco would take shorter time to process a loan when it has more funds. The results showed that 73.4 percent of the 
respondents agreed that their Sacco would take a shorter loan application turn-around time with more funds while 26.7 percent disagreed with the statement.

To determine whether the interest rates charged on loan by Saccos had any relation to the amount of funds that a Sacco had, the respondents were required to react to a statement that interest rate on loans depended on the amount of funds available. 93.3 percent disagreed with the statement and therefore it was eminent that availability of more funds does not affect the interest rates charged by Saccos on loans.

The respondents were also required to state whether their Saccos pegged the amount of loan given to a member on his accumulated savings. The results showed that 76.9 percent of Saccos pegged the amount of loan given to a member to the individual member's accumulated savings. This supports the argument by Baker and Biety [2] that a Sacco loan size is based on leveraging or a "multiple" of a member's share and deposit account balances, which guaranteed the loan. The ratio ranged from 3 to 4 times for most of the Saccos which is within the range of 3 and 5 times the sum of both shares and savings deposits suggested by Baker and Biety [2] and Omino [27].

To establish whether this ratio was fixed, the respondents were required to react to a statement that the loan to member's savings ratio is fixed. 78.6 percent of the respondents suggested that the ratio was fixed. This contradicts the argument by Omino [27] that this ratio is usually not fixed but depends on the Sacco's policy.

\subsection{Hypothesis testing}

In order to determine the effect of financing diversification on the Sacco performance, this study had set the hypotheses that: $\mathrm{H}_{0}$ - Financing diversification does not affect the performance of Saccos. Simple regression analysis beta $(\beta)$, which is the same as the Karl Pearson correlation coefficient $(r)$ was used to test the hypothesis with the test decision criteria set such that the study rejects the null hypothesis $\left(H_{0}\right)$ if $\beta_{1} \neq 0$, otherwise the study fails to reject $H_{0}\left(\beta_{1}=0\right)$. The hypothesis test was done at 5 percent $(0.05)$ significance level (within 95 percent confidence interval) which is significant for social sciences.

Correlating a mean value of financing diversification against an aggregate measure of performance revealed the following results

Table 1: Correlation results of financing diversification against performance Correlations

\begin{tabular}{|l|l|l|l|}
\hline & & Mean of Performance & Mean of financing diversification \\
\hline Mean of Performance & Pearson Correlation & 1 & $.634\left(^{*}\right)$ \\
& Sig. (2-tailed) &. & .011 \\
& $\mathrm{~N}$ & 15 & 15 \\
Mean of financing diversification & Pearson Correlation & $.634\left(^{*}\right)$ & 1 \\
& Sig. (2-tailed) & .011 &. \\
& $\mathrm{~N}$ & 15 & 15 \\
\hline
\end{tabular}

${ }^{*}$ Correlation is significant at the 0.05 level (2-tailed).

\section{Source: Research data, 2011}

The correlation results in Table 1 above showed that at 95 percent confidence interval, the correlation between the mean of financing diversification against the mean performance had a highly significant beta term (or $r$ ), $\beta_{1}=0.634$ ( $p$-value= $0.011<0.05$ ). Since the hypothesis test criteria was that the null hypothesis $\left(H_{0}\right)$ should be rejected if $\beta_{1} \neq 0$ (otherwise the study fails to reject $\left.\mathrm{H}_{\mathrm{O}}\right)$, then, on the basis of the above correlation results $\left(\beta_{1}=0.634 \neq 0\right)$ the study rejected the null hypothesis and concluded therefore that financing diversification affected the performance of Saccos.

To confirm the correlation results, regression analysis was done which revealed model results in table 2 . The regression results show that financing diversification had a positive linear effect on the performance of a Sacco. This means that as a Sacco diversifies its financing sources, its performance is expected to improve by $40.1\left(r^{2}=0.401\right)$ percent per unit diversity. This concurs with the findings by Cheps [7] that financing reforms increases a system's performance. The findings by Landi \& Venturelli [20] that diversification positively affected efficiency in terms of profits, costs and revenue growth support the linear relationship between financing diversification and Sacco performance. Additionally, these findings are in tandem by the argument by Markowitz [23] in his pioneering work on portfolio theory that diversification improves performance in terms of improved return and decreased risks. 
As shown in the regression results in table 2, the relationship between financing diversification and performance followed a simple regression model of the nature $Y=1.701+0.398 X$ where $Y$ is the estimated performance, 1.701 is a constant intercept term $\left(\beta_{0}=1.701\right), 0.398$ is the slope coefficient $\left(\beta_{1}\right), X$ is financing diversification.

To test whether the dependent variable contributed to the regression model, the study set out the hypothesis that Ho: $F_{\mathrm{V} 1, \mathrm{~V} 2,0.05}<\mathrm{F}_{\mathrm{V} 1, \mathrm{~V} 2,0.05}^{*}$. As Shown in the Anova section of the regression results, $F_{1 \mathrm{df}, 13 \mathrm{df}, 0.05}=8.717(p$-value $=0.011<0.05)$ which greater than the critical $F$ value $\left(\mathrm{F}^{\star}{ }_{1 \mathrm{df}, 13 \mathrm{df}, 0.05}=4.6672\right)$. The null hypothesis was thus rejected; therefore, dependent variable contributed to the regression model.

To test whether the regression parameters were significantly different from zero, the study set two null hypotheses that Ho: $\beta_{0}=0$ and Ho: $\beta_{1}=0$. Student $t$ distribution was used to test this hypothesis at 5 percent significance level and 13 degrees of freedom. The calculated $t_{.05,13 \mathrm{df}}=3.340$ ( $p$-value $\left.=0.005\right)$ for $\beta_{0}$ and $2.952(p$-value $=0.011)$ for $\beta_{1}$, both of were larger than the critical $t$ value $\left(t^{*} .05,13 \mathrm{df}=2.145\right)$. The null hypotheses were thus rejected and therefore the regression parameters $\beta_{0}$ and $\beta_{1}$ are significantly different from zero.

Table 2: Regression results of financing diversification against performance

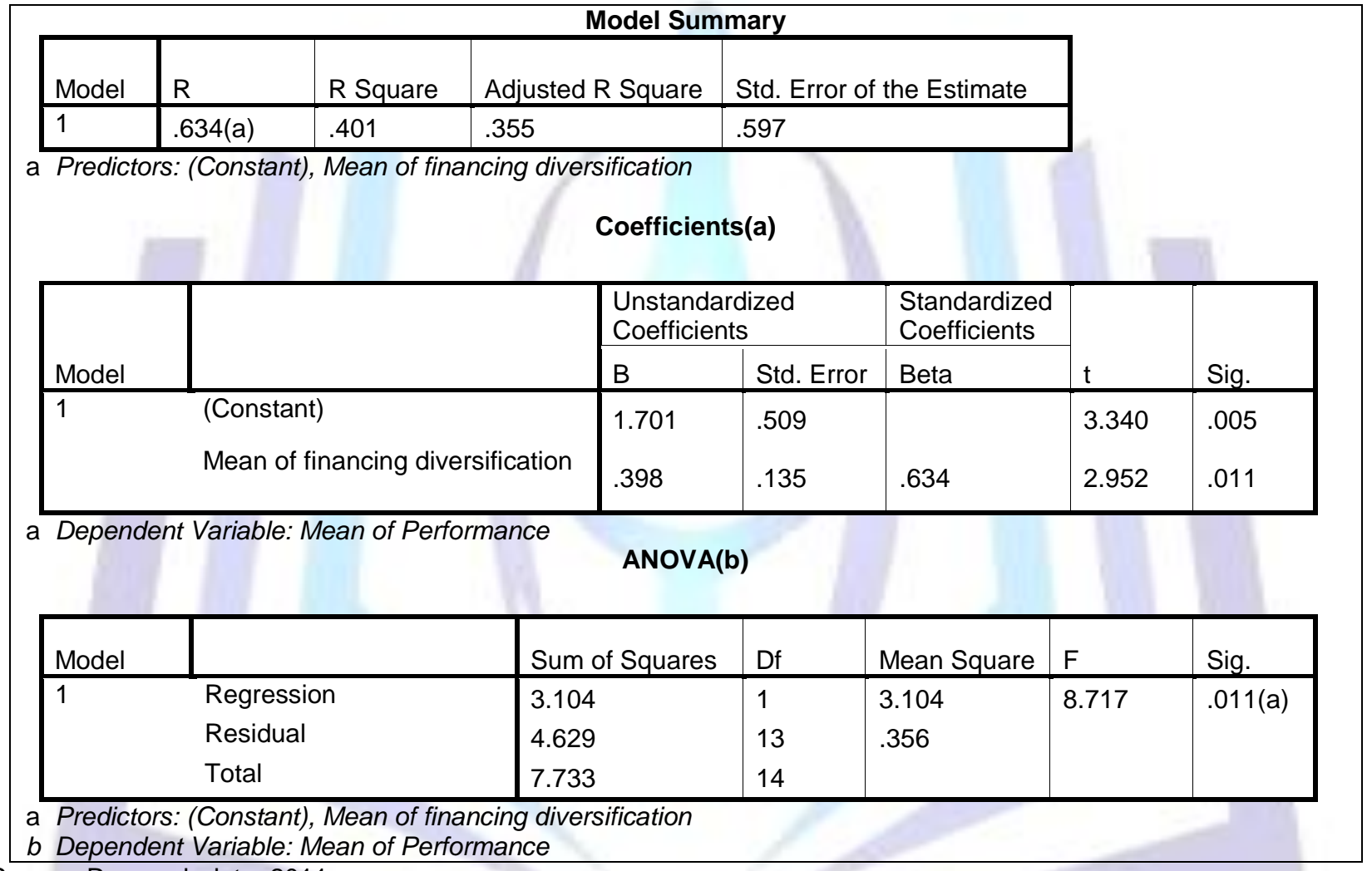

Source: Research data, 2011

\section{$6 \quad$ CONCLUSIONS}

The basic premise of this study was that financing diversification affects the performance of Sacco. The results of the study supported this premise since financing diversification was found to positively affect the performance of Saccos $(r=$ $0.634)$ with 40.1 percent $\left(r^{2}=0.401\right)$ of the variance in Sacco performance being explained by financing diversification. However it is not enough that in diversifying its financing sources, a Sacco just uses many sources but it is necessary that it avoids using sources with high co-variances among themselves. Markowitz [23] recommended such diversity in his hypothesis that the adequacy of diversification should not be thought by investors as to depend solely on the number of securities but on how different and diverse the securities are.

Based on this finding, this study recommends that Saccos need to diversify their financing sources as this improves the lending performance of the Sacco by increasing the amount of funds at the disposal of a Sacco and as a result an increasing the volume and the number of loans. However, it is necessary for further studies to be done to establish the risk implications of financing diversification in Saccos now that this study found out that Saccos have diversified their financing sources. 


\section{REFERENCES}

[1] Arora S. and Kaur S., (2009), "Internal Determinants for Diversification in Banks in India an Empirical Analysis", International Research Journal of Finance and Economics, Issue 24, Euro Journals Publishing Inc. (http://www.eurojournals.com/irife 24 15.pdf

[2] Baker C. and Biety M. M., (1998), "An analysis of Credit Union Microfinance Performance in Ecuador", World Council of Credit Unions, Office of Development Studies, United Nations Development Programme (UNDP) project, Madison, Wisconsin (http://www.microfinancegateway.org/gm/document-1.9.260533/302.pdf)

[3] BIS, (2010), "Funding patterns and liquidity management of internationally active banks", Committee on the Global Financial System, CGFS Papers No. 39, May (http://www.bis.org/publ/cgfs39.pdf)

[4] Bellco credit union, (2009), (hhtp://faqs.bellco.org/bellco/consumer/kbdetail.asp?kbid=308)

[5] Bottelberge P. and Agevi E., (2010), "Leading Change in Cooperatives and Member Based Organizations in East Africa; Findings of a study on leadership and leadership development", Swedish Cooperative Centre, September

[6] Chao-Beroff R., Cao T.H.H., Vandenbroucke J.P., Musinga M., Tiaro E. and Mutesaria L., (2000), "A Comparative Analysis of Member Based Microfinance Institutions in East and West Africa", Micro-Save, Nairobi, March

[7] Cheps, (2008), "Progress in higher education reform across Europe: Governance and Funding Reform", Volume 1. Institute of Education, University of London, (http://ec.europa.eu/education/higher-education/doc/funding/vol1en.pdf)

[8] DeYoung R. and Roland K. P., (1999), "Product Mix and Earnings Volatility at Commercial Banks: Evidence from a Degree of Leverage Model', Federal Reserve Bank of Chicago, WP-99-6, pp 3-4

[9] Federal Reserve Bulletin, (2004), "Flow of Fund Accounts", December (www.federalreserve.gov)

[10] Fiscal Policy Research Institute, (2010), "Regulation and Supervision for Sound Liquidity Risk Management for Banks" The Korean Institute of Finance, February (http://www.aseansec.org/documents/ASEAN+3RG/0910/FR/17b.pdf)

[11] Garland and Tweed (n.d.), "In pursuit of minimum acceptable response rates for mail surveys", Work in progress, Massey University, New Zealand: Palmerston North

[12] Huppi M. and Feder G., (1990), "The role of groups and credit Cooperatives in rural lending", The World Bank Research Observer, vol. 5, no. 2, July, pp. 187-204

[13] International Co-operative Alliance (ICA) and the Swedish Cooperation Centre, (2003), "Proceedings of the $3^{\text {rd }}$ ICA regional workshop on co-operative microfinance held at the Kenya School of Monetary studies", Regional office for East, Central and Southern Africa, July

[14] Kawach N., (2010), "Capitalisation of Oman banks to remain strong”, Emirates 24/7, March, (http://www.zawya.com/story.cfm/sidZAWYA20100321075928/Capitalisation\%20of\%200man\%20banks\%20to\%20 remain\%20strong)

[15] Kellie, (2010), "Isn't a Sacco Just a Bank?", The Rookie Manager; Learning the Ropes, November (http://www.rookie-manager.com/?p=179)

[16] Kenya Sacco network, (2011), (http://www.kenyasacconet.org/docs/investments.pdf)

[17] Kenya Union of Savings and Credit Cooperatives (http://www.kuscco.com/index.php?option=com content\&task=view\&id=9\&ltemid=12

[18] Kothari C.R., (2010), Research Methodology; Methods and Techniques, Second Revised Edition, New age international (P) Ltd. Publishers, New Delhi

[19] Kwame D. K., (2010), "How to Develop Risk Management and Savings Strategies in SACCOs" A paper presented in ACCOSCA SACCOs Leaders Forum, Johannesburg - South Africa, March (www.accosca.org/index.php?option=com phocadownload\&view=category\&id=4:slf-2010\&download=how-todevelop-risk-managem)

[20] Landi A. and Venturelli V., (2002), "The Diversification Strategy of European Banks: Determinants and Effects on Efficiency and Profitability" (http://www.papers.ssrn.com)

[21] Madura J., (2006), Financial Institutions and Markets, $7^{\text {th }}$ Ed., Thomson South-western, Singapore

[22] Madura J., (2008), Financial markets and Institutions, Indian Edition, Cengage Learning India Pvt Ltd., New Delhi

[23] Markowitz H., (1952), "Portfolio Selection", The Journal of Finance, American Finance Association, Vol. 7, No. 1, march, pp. 77-91

[24] Mishkin S.F. and Eakins S.G., (2007), Financial Markets + Institutions; Low Price Edition, $5^{\text {th }}$ Ed., Dorling Kindersley (India) Pvt. Ltd., Delhi, India 
[25] National Credit Union Administration (NCUA), (1994), "NCUA Letter to Credit Unions", Letter No. 161, December (http:// www.ncua.gov/letters/prior1996/e-let161.html)

[26] National Credit Union Administration (NCUA), (2010), "History of Credit Unions", Alexandria, USA, (http://www.ncua.gov/about/history.aspx)

[27] Omino G., - Central Bank of Kenya, (2003), "Regulation and Supervision of Savings and Credit Cooperative Societies (SACCOs) in Kenya", A paper presented at the $3^{\text {rd }}$ ICA regional workshop on co-operative microfinance held at the Kenya School of Monetary studies, July

[28] Owen G., (2007), "Rural Outreach and Financial Cooperatives: SACCOs in Kenya”, Agriculture and Rural Development (ARD)/The World Bank (http://vle.worldbank.org/bnpp/files/TF053594FinancialCooperativesCaseStudyKenya.pdf)

[29] Rose P.S., (2003), Money and Capital Markets; Financial Institutions and Instruments in a Global Market Place, $8^{\text {th }}$ Ed., McGraw-Hill//rwin, New York

[30] Santos J.R.A., (1999), "Cronbach's Alpha: A tool for assessing the reliability of scales”, Journal of Extension, Vol. 37, No. 2, Tools of Trade, 2TOT3, April

[31] SACCOL, (2011) (http://www.saccol.org.za/what is sacco.php)

[32] Saunders A. and Cornett M.M, (2007), Financial Markets and Institutions; An introduction to a risk management approach, $3^{\text {rd }}$ Ed., Tata McGraw-Hill publishing company, New Delhi

[33] Tache G.M., (2006), "Sustainable Sacco development", Rural Savings Promotion\& Enhancement of Enterprise Development (Rural SPEED), USAID/Uganda, September (http://pdf.usaid.gov/pdf docs/PNADK962.pdf)

[34] The SACCO Societies Act, (2008), Kenya Gazette Supplement No. 98 (Acts No. 14), NAIROBI, 30th December

[35] Tumpel-Gugerell G., (2009), "Business models in banking: Is there a best practice?" European Central Bank Euro System CAREFIN Conference, Bocconi University - Milan, September (http://www.ecb.int/press/key/date/2009/html/sp090921.en.html)

[36] United States International University (USIU) Sacco, (2005), "Strategic plan for the period 2005-2010" (http://www.usiu.ac.ke/sacco/docs/important\%20sacco\%20documents/sacco\%20-\%20Strategic\%plan.pdf)

[37] World Council of Credit Unions (WOCCU) and FSD Kenya, (2008), "Institutional Capital as Bulwark for a Rainy Day", SACCO CAP News, Newsletter of WOCCU/FSD Sacco CAP Project, Issue 3, July (http://www.Kenyasacconet.org/docs/issue 3.pdf)

\section{Author' biography with Photo}

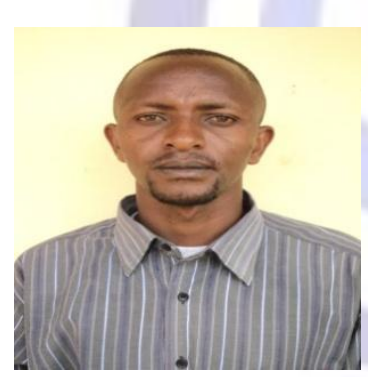

The author holds a First class honours Bachelor of Business Management (BBM) degree in Finance and Banking and a Master of Business Administration (MBA) in Finance both from Masinde Muliro University of Science and Technology, Kenya. He is currently pursuing a Doctor of Philosophy (Ph.D) degree in Finance from Moi University, Kenya. He has taught Finance, Accounting and Management Science courses as an Assistant lecturer in Masinde Muliro University of Science and Technology (2009 - June 2013) and currently as a Lecturer in Murang'a University College, Kenya. Before joining academia, he had worked in the banking industry with the National Bank of Kenya and the Kenya Commercial Bank. The author has research interests in investment, banking and corporate governance. 